\title{
Research on the Relationship between Government Size and Economic Growth
}

\author{
Junjun Chen \\ College of Economics, Jinan University, Guangzhou, China \\ Email: 769998006@qq.com
}

How to cite this paper: Chen, J. J. (2020). Research on the Relationship between Government Size and Economic Growth. Modern Economy, 11, 209-219. https://doi.org/10.4236/me.2020.112018

Received: December 31, 2019

Accepted: February 1, 2020

Published: February 4, 2020

Copyright $\odot 2020$ by author(s) and Scientific Research Publishing Inc. This work is licensed under the Creative Commons Attribution International License (CC BY 4.0).

http://creativecommons.org/licenses/by/4.0/

\begin{abstract}
This paper studies the relationship between government size and local economic growth in China. This paper uses the annual panel data of 29 provinces, municipalities and autonomous regions from 2007 to 2017 to use a fixed effect model for regression estimation. It is concluded that there is a significant positive correlation between the scale of local government and local economic growth. In the regional heterogeneity regression estimation, we found that the relationship between government size and economic growth is not significant in the eastern regions, while the relationship is significant in the central and western regions, which is a positive correlation. After using the robustness test of the replacement explanatory variables, the conclusions remain consistent.
\end{abstract}

\section{Keywords}

Government Size, Economic Growth, Fixed Effect Model

\section{Introduction}

Since China's reform and opening up, the government size in China has continued to expand. The average size of provincial governments has increased from $8.54 \%$ in 1978 to $13.98 \%$ in 2014 . In order to cope with the impact of the global financial crisis in 2008, the Chinese government introduced a strong 4 trillion RMB stimulus policy, but the macroeconomic operation gradually showed the dilemma of slowing growth. In 2014, it fell to 7.4\%. At present, economic development has entered a new normal. This is the inevitable result of China's supply-side reform and the transformation of the economic development structure. At this stage, Chinese economic goal is to transition from a high-speed growth stage to a high-quality development stage. According to the requirements of the 19th National Congress of the CPC, it is necessary to accelerate the 
clarification of the role of local governments in economic growth, so that the market will play a decisive role in resource allocation. However, in recent years, based on China's empirical evidence, Bai \& Zhang (2015) believed that the more resources the government department has, the fewer resources the private sector can obtain. The former squeezes the latter from the perspective of the size of government departments. The continued expansion of government size may cause a series of negative effects such as low administrative efficiency, crowding out effects, and rent-seeking corruption, which will ultimately harm economic growth. Economic fluctuations may negatively affect economic growth ( $\mathrm{Lu} \&$ Zeng, 2008). In fact, scholars at home and abroad do not have a unified conclusion that whether the government scale is "big" or "small" is more conducive to economic development. Because Chinese official governance and political system are more distinctive than other countries, this paper uses China's provincial panel data from 2007 to 2017 for empirical research, which is more representative and convincing. From the perspective of government size, it has practical significance to provide an empirical basis for exploring the path of economic growth in China's new normal.

\section{Literature Review}

Empirical research on the relationship between government size and economic growth, since the 1980s, domestic and foreign scholars have three main views. The first is that the expansion of government size can promote economic growth, and the empirical result is that there is a significant positive correlation. They advocate the "big government theory" and believe that expanding government size can strengthen the ability to intervene in the economy and promote economic growth. Rubinson (1977) uses the ratio of government income to GDP to measure government size. Using a large number of international sample data, he concludes that government size can reduce the "dependency" of less developed countries, especially the poorer less developed countries. Enlarging the government size will promote economic growth. In Ram's (1986) econometric analysis of the relationship between government consumption and economic growth, he found that government consumption promoted the increase in economic growth and the relationship between the two was significantly positive. This promotion effect is stronger in low-income countries than in high-income developed countries. Easterly and Rebelo (1993) empirical results believe that government investment expenditure as a proportion of GDP is positively correlated with economic growth rate. Especially, government spending on infrastructure such as road transportation, post and telecommunications has a significant role in promoting economic growth. Devarajan, Swaroop and Zou (1996) used data from 43 developing countries from 1970 to 1990 to test the relationship between various government expenditures and economic growth. Empirical results show that the proportion of recurrent expenditures in total expenditures is positively correlated with economic growth relationship. Miller and Russek 
(1997) found that the impact of government expenditure on economic growth in these selected sample countries was related to the way of obtaining funds through data regression. Increasing fiscal expenditure with tax increases will promote economic growth, while government spending due to national debt will hinder economic growth. Liu Lin (2005) conducted an empirical study on the causal relationship between government size and economic growth in China and he found that the cause and effect relationship of government scale economic growth is one-way and government size is positively related to economic growth. Barro (1990) conducted an empirical analysis of panel data from 30 developing countries in the 1970s and 1980s, studying the relationship between government expenditure and economic growth. The results show that the proportion of government investment expenditure in GDP is significantly positively related to economic growth rate. As the proportion of government investment expenditure in GDP increases, it will stimulate economic growth.

The second is the view of "small government theory". There is a significant negative correlation between government size and economic growth. Enlarging government size has not promoted economic growth, but has hindered it. Landau (1983) conducted regression analysis using relevant data from 1040-1977 of 104 countries and found that the actual GDP growth rate was significantly negatively related to the proportion of government expenditure in GDP. He believed that expanding government expenditure was not conducive to economic growth. Landau (1985) also analyzed economic variables such as the annual growth rate of real GDP per capita and government expenditure in 16 developed countries from 1952 to 1976. He found that the coefficient of the ratio of total government expenditure to national income was negative. Next year Landau (1986) used data from 65 less developed countries for 1960-1980 to conduct growth regressions and found that government consumption excluding defense and education accounted for a significant negative correlation between GDP and GDP growth. Grier and Tullock (1989) conducted regression analysis using 5-year average data from 1951-1980 of 24 OECD countries and 1961-1980 of 89 other countries. The increase in real GDP in Latin American countries is significantly negatively related to the increase in government consumption expenditure as a percentage of GDP. Guo, Lu, \& Zhang (2003) found that the total GDP growth rate of fiscal expenditure is negatively correlated and fiscal productive expenditure is positively correlated with economic growth. They believe that an increase in government consumer spending will have a negative impact on economic growth. Angeletos and Panousi (2009) believe that due to market defects, a large part of government expenditure cannot be converted into economic growth. In this case, the relationship between government expenditure and economic growth is negatively correlated. Chen (2018) used empirical examination of the provincial panel samples of China from 1978 to 2014 based on the 3SLS method shows that economic fluctuations have indeed promoted the expansion of the size of local governments, while the expansion of government sizes has inhibited economic 
growth.

The third is that the statistical relationship between government size and economic growth is not significant and there is no correlation. Kormendi and Meguire (1986) used a sample of 47 countries from 1961-1980 to perform a linear regression of total output growth and macroeconomic factors and he found that the average growth of real GDP has no significant relationship with the proportion of government consumption in GDP. Conte and Darrat (1988) used Granger causality method to analyze the relationship between real GDP growth and total government expenditure as a percentage of GDP in 22 OECD countries from 1960 to 1984. It is found that there is no causal relationship between the declining economic growth of OECD countries and the expansion of government departments. He also found that the economic growth of nine of these countries can get feedback from the size of the government sector. He believes that this feedback explains the significance of the size coefficient of government departments in previous studies, indicating that their conclusion that the expansion of government departments hinders economic growth is false. Levine and Renelt (1992) used data from 119 sample countries to conduct a sensitivity analysis of multinational growth regressions. He found that only by selecting a very specific set of conditions can we determine that the real GDP growth per capita from 1960 to 1989 had a significant partial correlation with the ratio of government consumption to GDP, and that when the proportion of exports to GDP was increased, the proportion of total expenditure was no longer significant. Nelson and Singh (1994) used data from nearly 70 less developed countries from 1970 to 1979 and 1980 to 1989 to find that the share of central government revenue in GDP had a negative impact on the economic growth of less developed countries in the 1970s, and Significantly. Agell et al. (1995) studied the OECD countries and added two population variables to the estimation equation, which caused the economic growth and government size to change from incomplete negative correlation to insignificant positive correlation.

It is not difficult to see from the above literatures that there is no definite conclusion about the relationship between government size and economic growth, and most of the literatures do not use Chinese data for empirical tests. The conclusions drawn may differ from the actual situation in China. Therefore, this paper starts from the level of local government, using panel data from 29 provinces in 2007-2017 to analyze the relationship between the scale of local governments and economic growth. Make the empirical results more in line with Chinese national conditions and more credible.

\section{Data and Empirical Models}

The data selected in this article are panel data from 29 provinces, municipalities and autonomous regions (excluding Tibet Autonomous Region and Hainan Province) from 2007 to 2017. The data are all from the database of the National Bureau of Statistics of China.

There are many opinions on the measurement and definition of economic 
growth in a certain area. The most famous one is the definition of Kuznets. He defined the economic growth of a country as a long-term rise in the ability to provide residents with an increasingly diverse range of economic products. This growing capacity is based on advanced technology and the corresponding adjustments of the required institutions and ideology. His point of view is not difficult to see that the performance of economic growth is an increase in economic products, that is, an increase in GDP. Therefore, Western economics usually regards economic growth as an increase in GDP or an increase in per capita GDP. But whether the economic growth is described by the increase of the total economic volume or the increase of the per capita volume, it is usually measured by the economic growth rate, that is, the growth rate. This paper chooses the measure of economic growth as the regional annual GDP growth rate.

In the economic literature, the difference in defining government size is much larger than the difference in defining economic growth. Scholars usually use three indicators to measure the size of government: first, the proportion of government expenditure in GDP; second, the number of government administrative agencies; third, the ratio of the number of government civil servants to the total population or employment. The most commonly used indicator of government size is the first indicator, which is the proportion of government expenditure to GDP. There is a positive correlation between this indicator and the size of government. The more the government spends, the larger the size of the government. For the second indicator, the number of government administrative agencies, for local governments at all levels, the number of administrative agencies does not differ much. It does not show how much the government consumes social resources, so the local government size cannot be explained well. The third indicator, the ratio of the number of government civil servants to the total population or the number of employed people does not reflect the proportion of the government's consumption of social resources and it is difficult to accurately reflect the size of the government directly. This paper uses the proportion of local government's general budget expenditure to local government GDP to measure the size of the government.

The measurement model is a fixed effect model of panel data, which is set as follows:

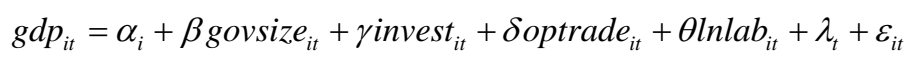

$g d p_{i t}$ is the GDP growth rate of city $i$ at year $t$, which indicates the economic growth situation. $r g d p$ represents GDP growth rate per capita. govsize $e_{i t}$ is the core variable of the model. It is the proportion of local government $i$ general budget expenditure in year $t$ to the GDP of the local government and it indicates $i$ government size.

According to Western economic theory, the level of economic growth will also be affected by other factors, mainly investment, capital accumulation, labor and trade. So we add three control variables invest ${ }_{i t}$, $\operatorname{lnlab}_{i t}$, optrade ${ }_{i t}$ to the model. invest $_{i t}$ is the proportion of the total investment in fixed assets of the region 
$i$ in the GDP of the region in the year $t$, which indicates the level of investment in fixed assets in the region. Inlab $b_{i t}$ is the logarithm of the number of employed persons in urban units in area $i$ at year $t$, indicating the main labor force impact in the area. optrade $e_{i t}$ is the proportion of the total import and export trade of region $i$ in the annual $t$ of the region's GDP, which indicates the degree of trade openness of the region. $\alpha_{i}$ is the urban fixed effect. $\lambda_{t}$ is the time effect. $\varepsilon_{i t}$ is a random interference term, indicating some uncertain factors besides the above variables. This paper uses fixed effect models, random effect models, and mixed OLS models for basic regression estimation.

Table 1 is a statistical description of the variables.

\section{Empirical Results and Analysis}

\subsection{Basic Model Estimation}

In the above results, model (1) represents a fixed effect model without any control variables. The result of the govsize coefficient is very significant and the coefficient is 0.783 , indicating that the relationship between government size and economic growth is positively correlated. Larger government size promotes economic growth. Model (2) is the estimated result of model (1) after adding three control variables. Model (2) is also a fixed effect model. From the regression results, the govsize coefficient is significantly positive, indicating that there is a positive correlation between government size and economic growth under the control of regional and time effects. This is because China is still in the middle stage of economic development and government investment and other activities will significantly stimulate economic growth. Infrastructure construction and the establishment of market departments are also inseparable from the government's participation. Without the government's participation, the market system will not improve spontaneously, and resources will not flow to backward areas. Therefore, the government should appropriately expand the scale of the government at the first stage and give play to the government's subjective initiative to promote China's economic development. Model (3) is a random effect model. The govsize coefficient is positive but not significant, which means there is no correlation between government size and economic growth. In order to verify whether a fixed effect model or a random effect model is more appropriate, the Hausman test is performed in this paper. The chi-square test statistic

Table 1. Statistical description.

\begin{tabular}{cccccc}
\hline Variables & Mean & Std. & Min. & Max. & Obs \\
\hline gdp & 0.127 & 0.071 & -0.224 & 0.323 & 290 \\
rgdp & 0.118 & 0.072 & -0.217 & 0.315 & 290 \\
govsize & 0.222 & 0.968 & 0.087 & 0.627 & 290 \\
invest & 0.712 & 0.226 & 0.240 & 1.371 & 290 \\
Inlab & 6.056 & 0.725 & 3.850 & 7.588 & 290 \\
optrade & 0.309 & 0.375 & 0.032 & 1.721 & 290 \\
\hline
\end{tabular}


from the specific test results is 47.88 and the null hypothesis is rejected at a significant level of $1 \%$. Therefore, the fixed effect model is more suitable, because the random effect model has limited explanatory power. Model (4) is the result of the mixed OLS regression model and the significance and positive and negative of the coefficients are consistent with the fixed effect model. In terms of control variables, the investment coefficient is significantly positive. It indicates that the more investment in social assets, the more it can promote economic growth, which is consistent with China's development model. It depends on a large amount of investment to drive economic growth, which is in line with Chinese national conditions. The labor cost coefficient is significantly negative, indicating that higher labor costs are more detrimental to economic growth, which may be related to China's industrial development structure. At present, the Chinese industry is dominated by the service industry and the high-level labor force does not match Chinese industry for the time being. Therefore, too high labor costs do not bring higher returns. Instead, it increases the production cost of the company, affects the development of the company, and then affects economic growth. The coefficient of trade openness is negative but not significant, indicating that the degree of trade openness has no effect on economic growth (Table 2).

\subsection{Regional Heterogeneity Regression}

As mentioned earlier, there are large differences in the natural geographical environment of the eastern, central and western regions of China. The resulting economic development methods are not the same and the level of economic development is uneven. Therefore, the effect of different government size on economic growth may also differ between different regions. Here are the regression results that distinguish regional heterogeneity (Table 3).

Table 2. Basic model estimation.

\begin{tabular}{ccccc}
\hline & $(1)$ & $(2)$ & $(3)$ & $(4)$ \\
\cline { 2 - 5 } & $\mathrm{FE}$ & $\mathrm{FE}$ & $\mathrm{RE}$ & OLS \\
\hline \multirow{2}{*}{ govsize } & $0.783^{* * *}$ & $0.598^{* * *}$ & 0.188 & $0.396^{* *}$ \\
& $(0.169)$ & $(0.232)$ & $(0.237)$ & $(0.178)$ \\
invest & & $0.180^{* * *}$ & $0.181^{* * *}$ & 0.045 \\
& & $(0.045)$ & $(0.043)$ & $(0.061)$ \\
optrade & & -0.168 & 0.010 & -0.098 \\
& & $(0.064)$ & $(0.046)$ & $(0.084)$ \\
Inlab & & $-0.250^{* * *}$ & $-0.210^{*}$ & $-0.110^{* * *}$ \\
& & $(0.046)$ & $(0.035)$ & $(0.072)$ \\
\hline$N$ & 290 & 290 & 290 & 290 \\
$R^{2}$ & 0.141 & 0.192 & 0.192 & 0.327 \\
\hline
\end{tabular}

Standard errors in parentheses, ${ }^{*} p<0.1,{ }^{* *} p<0.05,{ }^{* * *} p<0.01$. 
Table 3. Regional heterogeneity regression.

\begin{tabular}{cccc}
\hline & $(5)$ & $(6)$ & $(7)$ \\
\cline { 2 - 4 } & EAST & MID & WEST \\
\hline govsize & -0.305 & $0.339^{* *}$ & $0.698^{* * *}$ \\
& $(0.933)$ & $(1.003)$ & $(0.172)$ \\
invest & 0.188 & 0.104 & -0.081 \\
& $(0.177)$ & $(0.107)$ & $(0.087)$ \\
optrade & $-0.177^{*}$ & -0.133 & 0.046 \\
& $(0.080)$ & $(0.422)$ & $(0.175)$ \\
Inlab & $-0.212^{* *}$ & $-0.288^{* *}$ & $-0.339^{* * *}$ \\
& $(0.076)$ & $(0.111)$ & $(0.080)$ \\
\hline$N$ & 80 & 64 & 88 \\
$R^{2}$ & 0.290 & 0.335 & 0.450 \\
\hline
\end{tabular}

Standard errors in parentheses, ${ }^{*} p<0.1,{ }^{* *} p<0.05,{ }^{* *} p<0.01$.

From the estimation results, there are indeed differences in the relationship between government size and economic growth in the eastern, central and western regions of China. The govsize coefficient is negative but not significant in the east, while in the central and western region. The govsize coefficient is significant at a significance level of $1 \%$ and the coefficient is 0.698 . This shows that the government size in western China has a positive correlation with regional economic growth. The larger the government scale, the more it will promote regional economic growth. China's central and western regions are in the early stages of the economy and the degree of marketization is not high. Therefore, in contrast, the "invisible hands" of the government are needed to guide. Infrastructure, public services, business environment construction, etc. all need to be provided by the government, so the larger the government, the better the regional economic development. Eastern region is an economy region where has high degree of marketization and relatively perfect market regulations. Therefore, the role of market resource allocation can be brought into fuller play. Compared with government regulation, it is more efficient. On the contrary, government size will hinder economic development. The govsize coefficient is negative in the east, even if not significant and significantly positive in the mid and the west. Judging from the regression results by region, the interpretation of the basic regression results is verified once again. Economies in the early stages of economic development need more government guidance. The larger the government, the more favorable it is for economic development. For relatively developed economies, the government may hinder the regulation of economic development.

\subsection{Robustness Test}

The indicator of economic growth can be measured by the total GDP growth 
rate or the per capita growth rate. Therefore, we replace the explanatory variable GDP of the basic regression with RGDP for robustness testing. The model is as follows (Table 4):

$$
\operatorname{rgdp}_{i t}=\alpha_{i}+\beta_{\text {govsize }_{i t}}+\text { rinvest }_{i t}+\text { Soptrade }_{i t}+\text { Olnlab }_{i t}+\lambda_{t}+\varepsilon_{i t}
$$

According to the results, it can be seen that it is consistent with the basic regression results. In the entire sample, the results of the govsize coefficient are all significantly positive at a significance level of $5 \%$. This shows that there is a positive correlation between government size and economic growth. Similarly, when regression estimation is performed by region, the estimation results are also consistent. The govsize coefficient is not significant in the eastern region and is significant at the $1 \%$ significance level in the central and western regions. It shows that there is a significant positive correlation between government size and economic growth in the central and western regions. It will promote economic growth when the government size becomes larger.

\section{Conclusion}

Based on the provincial panel data of 29 provinces, municipalities and autonomous regions from 2007 to 2017, this paper uses the ratio of local government's general budget expenditure to local GDP to measure government size and uses local annual GDP growth rate for economic growth. In the basic regression, there is a significant positive correlation between the size of local governments and local economic growth, that is, the expansion of local government size is conducive to local economic growth. This is because China is currently in a period of economic development. In most areas, there are problems of low marketization, immature market legal system and imperfect public service facilities. Therefore, rather than the market's spontaneous adjustment of economic

Table 4. Robustness test.

\begin{tabular}{|c|c|c|c|c|}
\hline & (8) & (9) & (10) & (11) \\
\hline & ALL & EAST & MID & WEST \\
\hline \multirow[t]{2}{*}{ govsize } & $0.451^{\star *}$ & -0.220 & $0.205^{\star \star \star}$ & $0.715^{\star \star *}$ \\
\hline & $(0.170)$ & $(0.863)$ & $(1.055)$ & $(0.181)$ \\
\hline \multirow[t]{2}{*}{ invest } & -0.068 & 0.102 & 0.097 & -0.077 \\
\hline & $(0.060)$ & $(0.177)$ & $(0.103)$ & $(0.089)$ \\
\hline \multirow[t]{2}{*}{ optrade } & $-0.201^{\star *}$ & -0.165 & -0.170 & 0.073 \\
\hline & $(0.064)$ & $(0.080)$ & $(0.414)$ & $(0.181)$ \\
\hline \multirow[t]{2}{*}{ Inlab } & $-0.240^{\star * \star}$ & $-0.195^{\star}$ & $-0.304^{*}$ & $-0.363^{\star *}$ \\
\hline & $(0.047)$ & $(0.075)$ & $(0.112)$ & $(0.081)$ \\
\hline$N$ & 290 & 80 & 64 & 88 \\
\hline$R^{2}$ & 0.330 & 0.247 & 0.363 & 0.464 \\
\hline
\end{tabular}

Standard errors in parentheses, ${ }^{*} p<0.1,{ }^{* *} p<0.05,{ }^{* *} p<0.01$. 
resources, we should use the government's "invisible hands" to guide and give full play to the role of government regulation. Therefore, expanding government size can promote economic growth. In the sub-regional sample regression, the relationship between government size and economic growth in the eastern region is not statistically significant but there is a significant positive correlation between government size and regional economic growth in the central and western regions. The expansion can promote local economic development. This is because the eastern region has a relatively developed economy and a high degree of marketization compared to the central and western regions. It can play the role of market resource allocation. The size of the government may hinder economic development. However, the economy of the central and western regions is relatively backward. Enlarging government size and expanding government public expenditure are conducive to regional economic development. The robustness test results also confirm this conclusion. Due to the availability of data, this article uses macroeconomic data for regression. In future research, as far as possible, the empirical data should be based on corporate micro data, because this can more directly reflect the direct impact of government size on enterprises. As the core component of regional economic development, the future research will focus on micro-enterprise data to make the empirical results more credible.

\section{Conflicts of Interest}

The author declares no conflicts of interest regarding the publication of this paper.

\section{References}

Agell, J., Lindh, T., \& Ohlsson, H. (1995). Growth and the Public Sector: A Critical Review Essay. European Journal of Political Economy, 13, 33-52.

Angeletos, G. M., \& Panousi, V. (2009) Revisiting the Supply Side Effects of Government Spending. Journal of Monetary Economics, 56, 137-153. https://doi.org/10.1016/j.jmoneco.2008.12.010

Bai, C. G., \& Zhang, Q. (2015). Prospects for China's Economic Growth. New Finance Review, No. 6.

Barro, R. J. (1990). Government Spending in a Simple Model of Endogenous Growth. Journal of Political Economy, 98, S103-S125. https://doi.org/10.1086/261726

Chen, T. M. (2018). Economic Fluctuation, Government Size and Economic Growth: Transmission Mechanism and Empirical Tests. Economic Sciences, No. 4, 2.

Conte, M. A., \& Darrat, A. F. (1988) Economic Growth and the Expanding Public Sector: A Reexamination. The Review of Economics and Statistics, 70, 322-330. https://doi.org/10.2307/1928317

Devarajan, S., Swaroop, V., \& Zou, H. F. (1996). The Composition of Public Expenditures and Growth. Journal of Monetary Economics, 37, 313-344.

https://doi.org/10.1016/S0304-3932(96)90039-2

Easterly, W., \& Rebelo, S. (1993). Fiscal Policy and Economic Growth. Journal of Monetary Economics, 32, 417-458. https://doi.org/10.1016/0304-3932(93)90025-B 
Grier, K. B., \& Tullock, G. (1989). An Empirical Analysis of Cross-National Economic Growth, 1951-1980. Journal of Monetary Economics, 24, 259-276. https://doi.org/10.1016/0304-3932(89)90006-8

Guo, Q. W., Lu, B. Y., \& Zhang, D. Y. (2003). Fiscal Expenditure Structure and Economic Growth. Economic Theory and Economic Management, 11, 5-12.

Kormendi, R. C., \& Meguire, P. (1986). Government Debt, Government Spending, and Private Sector Behavior: Reply. The American Economic Review, 76, 1180-1187.

Landau, D. (1983). Government Expenditure and Economic Growth: A Cross-Country Study. Southern Economic Journal, 49, 783-792. https://doi.org/10.2307/1058716

Landau, D. (1986). Government and Economic Growth in the Less Developed Countries: An Empirical Study for 1960-1980. Economic Development and Cultural Change, 35, 35-75. https://doi.org/10.1086/451572

Landau, D. L. (1985). Government Expenditure and Economic Growth in the Developed Countries: 1952-76. Public Choice, 47, 459-477. https://doi.org/10.1007/BF00182148

Levine, R., \& Renelt, D. (1992). A Sensitivity Analysis of Cross-Country Growth Regressions. The American Economic Review, 82, 942-963.

Liu, L. (2005). Government Scale and Economic Growth-A Study of Causality Based on Rank. Social Science Research, No. 1, 40-44.

Lu, E. P., \& Zeng, W. Y. (2008). An Empirical Study on the Impact of Short-Term Fluctuations of Chinese Economy on Long-Term Growth in the Transition Period. Management World, No. 12, 10-23.

Miller, S. M., \& Russek, F. S. (1997). Fiscal Structures and Economic Growth: International Evidence. Economic Inquiry, 35, 603-613.

https://doi.org/10.1111/j.1465-7295.1997.tb02036.x

Nelson, M. A., \& Singh, R. D. (1994). The Deficit-Growth Connection: Some Recent Evidence from Developing Countries. Economic Development and Cultural Change, 43, 167-191. https://doi.org/10.1086/452140

Ram, R. (1986). Government Size and Economic Growth: A New Framework and Some Evidence from Cross-Section and Time-Series Data. The American Economic Review, 76, 191-203.

Rubinson, R. (1977). Dependency, Government Revenue, and Economic Growth: A Cross-Country Study. Southern Economic Journal, 49, 783-792. 